\title{
THE
}

$5-1984$

\section{Blue-Winged Teal Nesting in Hawaii}

Peter W. C. Paton

University of Rhode Island, ppaton@uri.edu

Avery Taylor

Philip R. Ashman

Follow this and additional works at: https://digitalcommons.uri.edu/nrs_facpubs

Terms of Use

All rights reserved under copyright.

\section{Citation/Publisher Attribution}

Peter W. C. Paton, Taylor, A., \& Ashman, P. (1984). Blue-Winged Teal Nesting in Hawaii. The Condor, 86(2), 219-219. doi:10.2307/1367050

Available at: http://dx.doi.org/10.2307/1367050

This Article is brought to you for free and open access by the Natural Resources Science at DigitalCommons@URI. It has been accepted for inclusion in Natural Resources Science Faculty Publications by an authorized administrator of DigitalCommons@URI. For more information, please contact digitalcommons-group@uri.edu. 


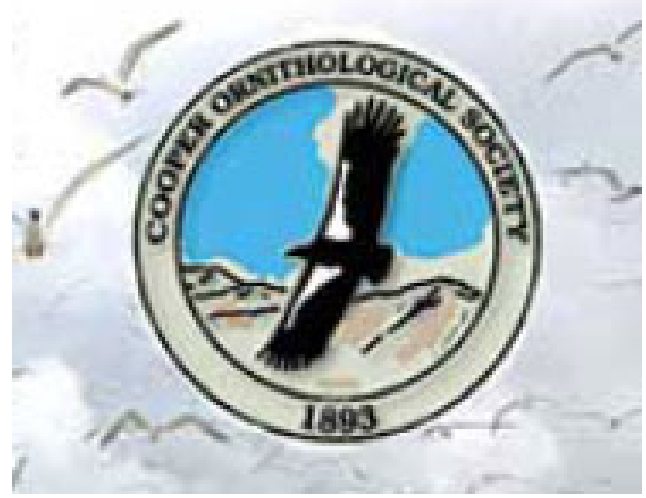

Blue-Winged Teal Nesting in Hawaii

Author(s): Peter W. C. Paton, Avery Taylor and Philip R. Ashman

Reviewed work(s):

Source: The Condor, Vol. 86, No. 2 (May, 1984), p. 219

Published by: University of California Press on behalf of the Cooper Ornithological Society

Stable URL: http://www.jstor.org/stable/1367050

Accessed: 06/03/2013 15:03

Your use of the JSTOR archive indicates your acceptance of the Terms \& Conditions of Use, available at

http://www.jstor.org/page/info/about/policies/terms.jsp

JSTOR is a not-for-profit service that helps scholars, researchers, and students discover, use, and build upon a wide range of content in a trusted digital archive. We use information technology and tools to increase productivity and facilitate new forms of scholarship. For more information about JSTOR, please contact support@ jstor.org.

University of California Press and Cooper Ornithological Society are collaborating with JSTOR to digitize, preserve and extend access to The Condor. 
The Condor 86:219

C) The Cooper Ornithological Society 1984

\section{BLUE-WINGED TEAL NESTING IN HAWAII}

\author{
PETER W. C. PATON \\ AVERY TAYLOR
}

AND

PHILIP R. ASHMAN

Blue-winged Teal (Anas discors) breed primarily in the prairie pothole region of North Dakota, South Dakota, Minnesota, and southern Alberta-Saskatchewan, and winter primarily in northern South America (for details see A.O.U. 1983). In the Hawaiian Islands they are uncommon migrants. They have been reported mainly from the island of Hawaii, but individuals and small flocks have sporadically been seen on Maui, Kauai, and Oahu (Berger 1981). Three males and three females visited Aimakapa Pond on Hawaii in the winters of 1977-1978, 1980-1981, and 1981-1982 (unpubl. data, Hawaii Division of Forestry and Wildlife [HDFW]; PWCP, pers. observ.). Furthermore, nine Blue-winged Teal were seen at Aimakapa and three at adjacent Opaeula Pond on 20 April 1983 (AT, pers. observ.). Thus, 28 of the 33 birds noted in recen years on Hawaii Island, have been on Aimakapa Pond (HDFW, pers. observ.).

Aimakapa Pond is adjacent to the ocean in a somewhat remote area on the west coast of Hawaii $\left(19^{\circ} 42^{\prime} \mathrm{N}\right.$, $\left.156^{\circ} 01^{\prime} \mathrm{W}\right)$. The 3-ha brackish pond has an average depth of $0.6 \mathrm{~m}$. It was formerly used by Hawaiians for raising fish, but was abandoned in the early 1960s. The surrounding vegetation is primarily the grasses Paspalum vaginatum, and Pennisetum clandestium and a forest of Hibiscus tiliaceus and Prosopis pallida. At the north end of the pond, where the teal were always seen, is a bed of Scirpus paludosus, Cyperus laevigatus, and Batis maritima; these plants probably provided food and cover, judging from the species' habits in North America (Palmer 1976).

On 13 June 1982, we discovered at Aimakapa Pond a pair of Blue-winged Teal with seven young, two-thirds grown. The pond was revisited on 18 June and the family was photographed (photo on file; Hawaii Audubon Society Rare Bird Photo Documentary File, Honolulu). The birds were not seen on 10 August, when the pond was next visited. Blue-winged Teal nested again at Aimakapa in 1983,11 young being noted in early June (AT, pers. observ.).

These are the first documented records of a migratory species breeding in the Hawaiian Archipelago (Berger 1981). As the world's most isolated island chain, the Hawaiian Islands receive relatively few natural immigrants. Their avifauna could have evolved from as few as fifteen suc- cessful colonizations (Olsoh and James 1982). Prior to these records, of waterfowl only the endemic species have been found breeding in the islands: Hawaiian Duck (Anas wyvilliana), Laysan Duck (A. laysanensis), and Hawaiian Goose (Nesochen sandvicensis). The Hawaiian Duck and the goose have breeding populations on the island of $\mathrm{Ha}$ waii, but not near Aimakapa Pond.

Of the 2,000 migrant waterfowl which presently reach the islands annually, the majority winter on Maui (53.6\%), with the other main islands being used: Oahu $(16.4 \%)$, Kauai (15.9\%), Hawaii (11.4\%), and Molokai (2.7\%) (data from 1968 to 1978, HDFW). Banding studies in the 1950s proved that Northern Pintails (Anas acuta) and Northern Shovelers (A. clypeata) reaching the Hawaiian Islands were not vagrants, but were in fact returning in subsequent years (Mederios 1958). Of the ducks that winter on the island of Hawaii, Northern Pintail have been the most abundant ( $\bar{x}=166$ birds annually; 1970 to 1980 , HDFW), with Northern Shoveler $(\bar{x}=63)$, Lesser Scaup (Aythya affinis) $(\bar{x}=15)$, and American Wigeon (Anas americana) $(\bar{x}=$ $5)$ also being observed consistently on the island. Bluewinged Teal have been seen regularly on Hawaii Island only since 1978 .

It therefore appears that the total number of individuals reaching an island cannot always be used to predict the success of colonization. Judging from the species of ducks wintering in Hawaii, pintails and shovelers would appear to be more likely candidates than Blue-winged Teal to be found breeding in the islands. Species-specific habitat requirements and present habitat conditions are probably more important factors in determining the outcome of potential colonizations. It remains to be seen whether Bluewinged Teal will continue to breed in the Hawaiian Islands.

We thank R. A. Ryder, F. Samson, C. Kepler, and S. Conant for comments on this manuscript.

\section{LITERATURE CITED}

AMERICAN ORNITHOLOGISTs' UnION. 1983. Check-list of North American birds, 6th ed. Am. Ornithol. Union. BERger, A. J. 1981. Hawaiian birdlife. Univ. of Hawaii Press, Honolulu.

Mederios, J. S. 1958. Present status of migratory waterfowl in Hawaii. J. Wildl. Manage. 22:109-117.

Olson, S. L., AND H. F. JAmes. 1982. Fossil birds from the Hawaiian Islands: evidence for wholesale extinction by man before western contact. Science 217:633635.

PALMER, R. S. 1976. Handbook of North American birds. Vol. 2. Yale Univ. Press, New Haven, CT.

Department of Fisheries and Wildlife Biology, Colorado State University, Fort Collins, Colorado 80523. Address of second author: General Delivery, Kamuela, Hawaii 96743. Address of third author: 2114 Bascom Street, Madison, Wisconsin 53705. Received 11 December 1982. Final acceptance 9 June 1983. 